\title{
COMPARATIVE CHARACTERISTICS OF LINGUISTIC FEATURES OF BUSINESS LETTERS (ENGLISH-UKRAINIAN PARALLELS)
}

\author{
Olha BLASHKIV
}

\author{
PhD in Philological Sciences, \\ Assistant professor of the Department of Information and Socio-Cultural Activities, \\ West Ukrainian National University, \\ Ternopil, Ukraine \\ https://orcid.org/0000-0002-6233-9558
}

DOI 10.25128/2304-1222.20.51.07

\begin{abstract}
The article focuses on one of the central issues of comparative linguistic and stylistics which consists in singling out of convergent and divergent linguistic features of official-business letters written in different languages. It aims to describe those most conspicuous homologous and distinguishing characteristics of English and Ukrainian officialbusiness style documents that should constitute the subject of special attention in situations of interlanguage communication. The revealed peculiarities are explained taking into account the intercultural specifics of the participants of business written communication. In particular, the national specifics of the construction of English and Ukrainian written language, socio-cultural properties of the written language.
\end{abstract}

Keywords: Ukrainian, English, business letter, linguistics, content, addressant, addressee, communication.

У статті зосереджено увагу на одній з центральних проблем порівняльної лінгвістики та стилістики, яка полягає у виокремленні збіжних та розбіжних мовних особливостей офіційно-ділових листів, написаних різними мовами. Вона має на меті описати ті найпомітніші гомологічні та відмінні характеристики англійської та української документації офіційно-ділового стилю, які повинні становити предмет особливої уваги у ситуаціях міжмовного спілкування. Виявлені особливості пояснюються 3 урахуванням міжкультурної специфіки учасників ділового письмового спілкування, зокрема, національної специфіки побудови англійської та української писемної мови і соціально-культурних властивостей писемної мови.

Ключові слова: українська мова, англійська мова, діловий лист, лінгвістика, зміст, адресант, адресат, спілкування.

Artykuł koncentruje się na jednym z centralnych zagadnień lingwistyki porównawczej i stylistyki, polegającym na wyodrębnianiu zbieżnych i rozbieżnych cech językowych listów urzędowo-biznesowych pisanych w różnych językach. Celem jest opisanie tych najbardziej widocznych, homologicznych i wyróżniających cech angielskich i ukraińskich dokumentów o charakterze urzędowo-biznesowym, które powinny stanowić przedmiot szczególnej uwagi w sytuacjach komunikacji międzyjęzykowej. Ujawnione osobliwości są wyjaśniane z uwzględnieniem międzykulturowej specyfiki uczestników pisemnej komunikacji biznesowej, w szczególności specyfiki narodowej budowy angielskiego i ukraińskiego języka pisanego oraz społeczno-kulturowych właściwości języka pisanego.

Słowa kluczowe: język ukraiński, język angielski, list biznesowy, język, treść, adresat, adresat, komunikacja.

\section{Introduction. Assignment formulation}

The modern world is characterized by a tendency to expand and deepen international contacts in various spheres of economic, socio-political, social and cultural life. This determines the need to address the problems of intercultural communication. However, in the presence of mutual interest of representatives of different cultures, communicants are often unfamiliar with the peculiarities of communicative behaviour of representatives of another linguistic and cultural community. 
Today in Ukraine the cooperation of Ukrainian organizations, institutions and companies on the international market is progressing more and more intensively, due to which the interest in the problems of the language of business communication and the culture of business communication is rapidly growing. Accordingly, the requirements for specialists: philologists, records manager with knowledge of a foreign language, and the need to revise the standards of learning a foreign language, because modern graduates do not receive a high level of knowledge of English business terminology, multicultural communication strategies and need to improve their language skills. in particular in a foreign language, in modern business conditions. Business written communication is a type of business writing that belongs to the functional style of official documents. The purpose of communication of this style is to establish ties and conditions of interaction between the two parties, which can be: the state and citizens, society and its members, enterprises and companies, governments.

\section{Previous publications on the topic}

There is a significant amount of scientific research in the English-language scientific literature devoted to the study of various language issues of official business letters, and many issues on this topic are covered in Ukrainian scientific works. In particular, many scholars have studied such aspects of the official style as legal language and texts of diplomacy, in particular, in the scientific works of P. Damova [2007], B. Danet [1985], R. Hiltunen [1990], D. Kappeler [2001], N. Kryvchikova [2015], N. Lisina [2013], O. Matsko [2000], V. Shabunina [2012]. However, this type of business writing, such as official business letters, remains insufficiently studied from a linguistic point of view. Although traditionally in the linguistic aspect, this is of great importance mainly in practical textbooks in English, which offer numerous very valuable linguistic observations [see, for example, Ashley 2000; Danet 1985]. It is worth noting that a number of works related to the actual business correspondence, offer quite interesting and promising topics open for further scientific discussion. This is, for example, the question of the art of convincing business "organizational" writing, which was engaged in L. Bielawski [Bielawski, Parks 1987], sensitive and insensitive business messages [Shabunina 2012]; research of separate language priorities that ensure excellence in business communication [Thill, Courtland 1993]; certain stylistic features of official-business texts written in different languages [Doubenko 2017].

At the same time, although there is a significant amount of research focusing on the style of official business discourse in the English and Ukrainian traditions, it should be noted the lack of thorough comparative work in the field of science. Although the relevance of such a comparative analysis seems unquestionable, given the need to provide a solid linguistic basis for both linguistic and translatological research. Therefore, the aim of this paper is comparative description of the most important convergent and heterogeneous language features of official business letters in English and 
Ukrainian, ie texts of different cultures, and to improve the linguistic competence of students to explain the identified peculiarities taking into account the intercultural specifics of business written communication.

\section{Homologous features and discriminants of English and Ukrainian official-business correspondence. Level of communicative competence.}

The practice of working at the university shows that most students often face the need to write business letters in Ukrainian or English or they have such an opportunity in the future. However, students who study English or Ukrainian as a foreign language, even if they have theoretical knowledge of the requirements for the structure and format of a modern business letter, however, do not have enough lexical and grammatical skills needed to write business letters. In addition, students do not have sufficient communication skills related to written business communication in a foreign language. A high level of communicative competence presupposes a linguistic, ethical, actually communicative component, rhetorical literacy, expressiveness and creative originality of language. In this situation, it seems appropriate to introduce a separate course of English-language business correspondence in order to better master students of lexical and grammatical phenomena of modern business English. The impetus for the introduction of such a course is the need to develop skills and abilities to analyze the text of a business letter from the standpoint of both traditional (text linguistics, communication theory) and modern approaches to its study (discourse analysis, semiotics, cognitive linguistics); understanding the multifaceted characteristics of the text of business topics from the standpoint of cognitive linguistics as a structural unit of speech communication in the subject area "business" - the text of English business writing and a complex phenomenon that includes linguistic and extralinguistic characteristics; as well as from the standpoint of pragmalinguistics, the interests of the study of which includes many problems, not limited to the analysis of the relationship between the sign and its interpreters, ie the addressee and the addressee, as well as studying the impact of context and background knowledge on communicators. speaker in speech acts, etc.

\section{Intentional content}

A business letter is a class of documents united by a common intentional content (communicative idea) and characteristic ways of cognition that implement this communicative idea. And despite the fact that the texts of official business style documents are diverse and heterogeneous, yet all business texts have common features. At the lexical level it is the use of neutral and bookdocumentary vocabulary, as well as professional terminology, at the level of syntax - the selection of specific means of expression of modality, clichés of the most commonly used formulations, the complexity of syntactic structures. In addition, the constant features of the style of official documents 
include formality, accuracy, conciseness, stereotypes, logic, as well as emotionlessness and personification.

Naturally, students who already have the skills and abilities of business correspondence acquired in the course of studying the courses "Ukrainian business language", "English business language", use their linguistic and educational experience in trying to write business letters in a foreign language and, of course, defining a feature of the practice of their foreign-language business correspondence is the positive transfer and application of this experience. Examples of writing business letters in Ukrainian are used by students as examples of the external structure of constructing texts of this type in a foreign language, to translate the features of compositional design, to compare basic grammatical constructions and their lexical equivalents.

However, when writing a business letter, the bearer of a certain culture uses the knowledge, experience, characteristic of business correspondence in his native culture; uses frames, relies on the values of its socio-cultural environment. Under socio-cultural components we understand knowledge about the peculiarities of the country's culture, the mentality of the foreign society (in our case, the British), knowledge of the national specifics of the construction of written texts in English, including business letters.

\section{Nominative content}

Comparative analysis of English and Ukrainian business letters allows you to select individual parameters for comparison: composition, nominative and communicative content of business correspondence.

In the concept of "nominative content" we invest the understanding of it as a set of elements of the situation of reality, present in the mind of the individual, which are reflected in the texts, determining the specifics of the choice of language in forming the text.

English business letters contain the following elements of nominative content:

1) fully specified date (day, month, year);

2) internal address (name, position, name of the company, full name, postal code);

3) greetings;

4) the title, which sets out the main idea of the letter;

5) the initial paragraph, which provides a reference to the date of the letter that led to the writing of the answer;

6) the main part of the letter, which indicates the event;

7) the final paragraph, which contains the intention and expectations of the sender regarding possible actions of the addressee in the future;

8) the final formula of politeness;

9) handwritten signature; 
10) surname and position of the addressant;

11) in the presence of appendices to the letter a mark about them.

In Ukrainian business letters, the nominative content is presented with less intensionality and contains such components as:

1) the name of the institution / establishment;

2) site address,

3) the specified position;

4) full name of the addressant;

5) appeal to the addressee;

6) the subject of the letter;

7) the initial paragraph, which provides a reference to the date of the letter that led to the writing of the answer;

8) the main part of the letter, which indicates the event;

9) the final paragraph, which contains the intention and expectations of the sender regarding possible actions of the addressee in the future;

10) handwritten signature;

11) surname and position of the addressant;

12) in the presence of appendices to the letter a mark about them.

In the texts of letters written in the Ukrainian language, there is a tendency to "silence" part of the information, thus narrowing the information field. A comparative analysis showed that information about the position of the sender and addressee, the name of the institution, as well as its coordinates are not always mandatory for Ukrainian-language business letters.

The proposed table (Table 1) shows the ratio of the above elements of nominative content in business letters written in Ukrainian and English.

Table 1.

\begin{tabular}{|l|c|c|}
\hline \multicolumn{1}{|c|}{ Elements of the reference situation } & Ukrainian letters & English letters \\
\hline Addressant information & & $100 \%$ \\
\hline Position, regalia & $60 \%$ & $100 \%$ \\
\hline Full Name & $100 \%$ & $100 \%$ \\
\hline Name of institution / organization & $65 \%$ & $100 \%$ \\
\hline Coordinates (address, fax, telephones) & $57 \%$ & \\
\hline Addressee information & & $92 \%$ \\
\hline Position, regalia & $73 \%$ & $100 \%$ \\
\hline Full Name & $100 \%$ & $100 \%$ \\
\hline Name of institution / organization & $78 \%$ & $100 \%$ \\
\hline Coordinates (address, fax, telephones) & $90 \%$ & \\
\hline
\end{tabular}


Based on a comparative analysis of English and Ukrainian business letters, we identified features of a common and different nature. In particular, regarding the difference in their nominative content, in the texts of business letters written in Ukrainian, there is a tendency to "silence" information.

\section{Communicative content}

Communicative content reflects the attitude of the addressee to the message, the participants of communication and the situation and is manifested in the use of heterogeneous grammatical phenomena associated with the conceptual category of modality, in particular: the expression of obligations, desires, will. Modality is responsible for the addressee's desire to influence the addressee. The choice of means of expression of modality depends on the communicative task of the text of the business letter. The business letter uses a fairly wide range of means of expression of modality, presented at different levels: grammatical (method), lexical, lexico-grammatical (modal verbs), lexical-phraseological (to be glad, to be kind, to be happy, to be sorry, to be able, to be sure, to be pleased, to look forward to / paдіти, бути добрим, радіти, шкодувати, бути спроможним, бути впевненим, бути задоволеним, з нетерпінням чекати). Business letters distinguish between neutral communication, reflected in the meaningful message of the letter, and stylistically colored communication, which allows the author to use different stylistic devices to influence the recipient explicitly or implicitly. Letters with an explicit position of the author contain phrases with a clear interest in establishing business contact and provide for the subordination of these phrases to the purpose of influence.

The desire to interest the addressee can be expressed and implicit (you will be interested to learn, you will note, as уои are aware, as promised to уои, this helps уои / вам буде цікаво вивчити, ви зауважите, як вам відомо, як вам обіцяли, ие вам допомагає), thanks to skillfully selected arguments, the recipient is encouraged to act. From the point of view of the category of modality represented by semantic-stylistic, lexical, grammatical means of expression, in Ukrainian-language business letters the modal meaning of obligation dominates, and also the vector orientation from the addressee to the addressee is observed, and in business letters written in English.

Another communicative (or "rhetorical", as it is often called by some foreign authors) is the need to plan written discourse so as to adequately express their communicative intention, while adhering to the general requirements for business letters [Dȧmová 2007: 50]. This problem is not identical with the issue of language conventions, as the latter is mainly related to the mixing of functional styles (ie is a purely linguistic point), and does not contain a clear communicative basis. It's about the "hygiene" of the text.

Consider a specific example: the author of the letter, an employee of the company " $\mathrm{X}$ " must give a written response to the request of the correspondent to sell a particular product. The letter 
should inform the addressee that the company " $\mathrm{X}$ " is engaged only in the production and not the sale of goods, so the customer's request can not be satisfied. Such a communicative intention can be expressed in different ways, however, it should be borne in mind that not all of them are appropriate to apply in the practice of business correspondence, even if the style of business writing. For example, a wording such as 'We are sorry to inform you that we refuse to sell directly to the public' is quite grammatically correct, however, it is not recommended for use in a business letter because it violates the unspoken rule of business correspondence: refusal should not be expressed directly.

The best strategy for communicating with a client or colleague is to show respect and care, so using lexical items such as 'refuse' / «відмовити» is completely undesirable. It is best to construct a sentence in this situation as follows: 'We are sorry to inform you that we sell only through our authorized distributors'/ 3 прикрістю повідомляємо, щз ми продаємо лише через наших уповноважених дистриб'юторів. It is also appropriate to indicate the contact details of the distributors that the customer can contact to resolve their issue.

The above and similar examples lead students (even those who have well-developed communication skills in both Ukrainian and English) to think that writing business letters is quite a difficult task.

Thus, when developing written communication skills in students studying English as a foreign language, it is necessary to rely on productive models of text creation, overcoming communication barriers, as well as to avoid the transfer of clichés from the native language.

\section{Nominative content}

The communicative content of the letter, of course, forms the vocabulary. It should be noted that in English, as well as in Ukrainian, in addition to common vocabulary, the language composition of business letters covers the following units:

- first, these are components inherent in the language of business communication in general (for example, typical verbs using verbs used to describe business activity: to inform, to postpone, to reinforce, to schedule // повідомити, відкладати, підкріплювати, планувати);

- secondly, the units characteristic of written business communication (for example, the main terms: response to the invitation, inquiry, salutation, postscript, resume, letter of acknowledgment / відповідь на запрошення, запит, привітання, постскрипт, резюме, подяка);

- thirdly, elements typical of specific situations required to write a certain type of business letter (for example, to write a cover letter to a financial document: invoice, Letter of Credit, airway bill / рахунок-фактура, акредитив, вексель ).

To properly select lexical items and organize them, you need to understand how they affect the effectiveness of written business communication. A study of reference and information literature and 
texts of business letters shows that there are several groups of lexical items that are most often used for written communication.

The first group of such elements includes verbs that characterize business activity in general (to conduct, to direct, to manage / проводити, спрямовувати, керувати, etc.). Systematization and interpretation of general scientific information, as well as contextualization, analysis and synthesis of ideas and views of professional practitioners allowed to identify a certain relationship between the nature of verbs used in this group and the effectiveness of written business communication in general: less used, but more specific and specific. verbs of this group, the greater the effect on the interlocutor. Such interconnection and interdependence of language phenomena and communicative tasks allow to develop an effective strategy of effective communication.

The second group is formed by the most frequently used lexical units: words and phrases that characterize the professional and business skills of managers as representatives of a particular specialty (HR Manager, Financial Manager, Marketing Manager / Менеджер 3 персоналу, фінансовий менеджер, менеджер з маркетингу, etc.).

The third group (which can be divided into several subgroups) includes terms that denote the main concepts of various areas of professional activity (for example, the field of employment is defined: to apply, to qualify, candidate, application, interview / подати заявку, претендувати, кандидат, заява, співбесіда).

The results of the comparative analysis showed that business and neutral vocabulary is dominant in the texts of English business letters, while in business letters written in Ukrainian, everyday words and evaluative-expressive vocabulary appear in the texts (see Table 2).

Table 2

\begin{tabular}{|l|c|c|}
\hline \multicolumn{1}{|c|}{ Lexical means } & Ukrainian letters & English letters \\
\hline Conversation vocabulary & $51,2 \%$ & $30 \%$ \\
\hline Official vocabulary & $48,8 \%$ & $70 \%$ \\
\hline Evaluative-expressive vocabulary & $37 \%$ & $19 \%$ \\
\hline Neutral vocabulary & $63 \%$ & $81 \%$ \\
\hline
\end{tabular}

The selection of grammatical structures should also be carried out in accordance with the criteria of effective written communication. In particular, the following constructions are typical for business letters of English correspondence:

- frequent use of the conditional sentence (We would be happy to offer you the most favorable conditions on the case-to-case basis. We would be grateful if you could... / Ми будемо padi запропонувати вам найвигідніші умови для кожного конкретного випадку. Ми були б вдячні, якщзо б ви могли ...);

- the use of inversion forms at the beginning of the of the conditional sentence (Should you fail to deliver in time ... Якщо ви не зможете доставити вчасно ...); 64 Studia methodologica, ISSN 2304-1222, No. 51. 2020 
- use of independent adverbial and adverbial inflections at the beginning of the sentence (Having received your message ... Taking into consideration the job market ... /.../ Ompимавши ваше повідомлення ... Беручи до уваги ринок праці ...);

-use of conjunctions and connective word (not only ... but ..., as well as, in spite of, although .../ не тільки ... але ..., а також, незважаючи на, хоча і под.).

Often in the texts of business letters a conditional sentence is used in order to reduce the categoricalness of the statement. Of the fifty original English business letters analyzed by individual foreign commercial companies, the following phrases are the most common: We would be pleased / Ми були б задоволені; We would be quite willing / Ми були б цүілком охочі; If уои would send те a сору of уоur catalogие / Якби ви надіслали мені копію свого каталогу.

The conditional sentence adds to the meaning of the statement of a certain assumption, probability and hypothetical, thereby increasing the distance between the content of the statement and its pragmatic meaning, as well as implicitly expresses the transition of initiative from addressant to addressee.

The use of modal verbs would, could and might avoids straightforwardness, as well as to vary the rate of mandatory action, for example: We would be grateful if you could .../ Ми були б вдячні, якщо б ви могли ... They are included in a number of stable formulas of politeness in the form of interrogative and conditional constructions in which distance of the addressant and the addressee is differently shown: Could/would you send замість Will you send / Не могли / не міг би ти надіслати замість Чи б ти надіслав; I would like instead I want / Я хотів би instead я хочу.

Using the conditional sentence allows to formulate questions quite evasively so that a possible refusal does not sound rude and the help or service is not intrusive: I would really like to say yes/help, but.../ Я б дуже хотів сказати так / допомогти, але ...

Modal verbs are often used with the conjunction if to formulate a polite question, sentence, or requirement. In this way, the addressee has a choice - to accept or reject the offer.

The equivalent of English modal verbs expressing a sentence, a request, in the Ukrainian language is the word: будь ласка оr будьте ласкаві.

\section{I- and You-oriented position}

On the basis of M. Buber's theory of dialogue [Buber 1964], in which the relationship "I-You" is considered as an inseparable unity due to culture, I-You-position becomes a way to establish relations between partners.

In the process of communication, individuals take an I- or You-oriented position. Characteristic features of self-oriented communication are interaction with a communication partner, built only on personal judgments, assessments and relationships, self-focus, confirmation of one's own opinion. This position is close to the modal content. 
You-oriented communication is characterized by a focus on the interlocutor, focus on both own and his interests trust in his knowledge and experience, as well as the level of his awareness, as well as informational saturation. You-position provides nominative content.

Involvement of one of the position of communication is reflected in the structure of the text, as well as in the choice of lexical and syntactic means when writing a business letter. The use of evaluative-expressive vocabulary and the pronounced modal orientation of the text of business letters gives grounds to conclude that Ukrainian-language business letters have an I-oriented position. Instead, the desire to avoid value and modality suggests that English business letters are You-oriented.

Interestingly, the distance between communicators in the Ukrainian language is affected in speech by the use of pronouns $m u$ and $в u$, a phenomenon that is not inherent in the English language. Depending on the address to $m u$ or to $b u$, the necessary grammatical forms of the verb are used, as well as the speech formulas of greeting and farewell. The duality of $m u$ - and $b u$-address is another example of evidence of a significant distance between communicators, which is reflected both in the culture of society and in its written communication.

There are many other examples that can illustrate the differences in Ukrainian and English business letters, as well as confirm the influence of cultural specifics on language expression. In particular, the Ukrainian culture has adopted a three-name system of naming people. In English culture, we meet many cases of contacting a business communication partner only by name. Such appeals to a business partner of Ukrainian origin can be interpreted as frivolous, while appeals by patronymic are a sign of respect and a way of additional differentiation.

Another rather popular topic for discussion of Ukrainian authors of business correspondence is the writing of the pronoun "Ви" in an address to one person as a sign of special respect in uppercase or lowercase. Some experts on the culture of business communication believe that writing with a capital letter indicates a respectful attitude, while others, more modern researchers consider it normal to write the pronoun "ви" in lower case. Of course, if in a letter we address a very respected person, such as a clergy of Established churches (patriarch, metropolitan) or a person holding a high state position (president, rector, etc.), it is appropriate to write "Ви". After all, firstly, you do not know his/her advantages, and secondly, he is a very respectable person and you need to make it convenient for the person and you. However, in modern business letters of Ukrainian business correspondence there is an increasing tendency to write the pronoun you in lower case. Politeness in English business letters is also achieved through the use of stylistic devices, syntactic constructions: complex conjunctions, passive constructions instead of the active, full grammatical forms instead of abbreviated.

\section{Choice of personal pronoun}


Since the author of the letter acts as a representative of the firm, we can conclude that the norm of business communication included the use of the personal pronoun in the plural. However, recently there has been a transition from the use of the personal pronoun in the plural to the use of uncharacteristic for a business letter personal pronoun of the first person singular I. In the analyzed material, both options are presented. The tendency in which self-consciousness predominates emphasizes the affiliation of the English language to individualistic culture. The personal pronoun singular is used only when the letter is addressed to an acquaintance. The personal pronoun is always written in capital letters, which is also inherent in the culture of individualism.

\section{Evasion strategy}

The principles of avoidance or evasion strategy are used in the English business letter to soften the categorical statements. The essence of this strategy is to avoid responsibility for the objectivity of the statement by emphasizing one's own opinions or shifting the emphasis to common opinion.

To create a similar effect, modal modifiers are used, focused on the recipient, passive constructions, impersonal and definite-personal sentences: The fact that we are the largest suppliers ... ( Той факт, щуо ми є найбільшими постачальниками ...) - the communicant abdicates responsibility for the statement, emphasizing the influence of generally accepted opinion on his statement.

As far as I know, Bass \& Company models have already been well received ... (Наскільки мені відомо, моделі «Бас і Компанія» вже чудово сприйняті ...) - in this sentence, the author uses two means to shift the emphasis to the common opinion - a modal modifier (as far as I know / наскільки мені відомо) and the use of the passive state (have been received / вже сприйняті).

Thus, the addressant assumes the existence of judgments different from his opinion, that is, gives the addressee the opportunity to assess his views and, possibly, to express their own. This fact confirms the dominance of You-oriented communication in English communication.

The passive voice implements evasion tactics. Here, the performance of the action expected of the addressee is not a prerequisite, but rather compliance with generally accepted rules. The addressee manages to avoid pressure on the addressee, the statement acquires a shade of possibility:

We should like ... to ask you to explain why the bill was not honoured (Ми хотіли б ... попросити вас пояснити, чому законопроект не був дотриманий),

Delivery should be made by... (Доставка має бути здійснена ...),

Our account for cutlery supplied to you on 21 October has not been paid (Haа рахунок за столові прилади, щуо постачалися вам 21 жовтня, не сплачений). 


\section{Conclusions}

Thus, for business written communication, in many respects formalized and hierarchically structured, it is necessary to adhere to the principles of politeness and cooperation (formulated by G. P. Grice and J. Leach [1983]), because they are integral, universal and contribute to the harmonization of any type of communication.

By comparing the ways of constructing a business letter of typologically different languages (English and Ukrainian), which have fundamental differences in the ways of forming nominative units, however, there are general patterns and structural differences.

Similar features inherent in Ukrainian and English letters are the dominance of communicative content over nominative; minimum information. Nevertheless, the monitoring of business correspondence in Ukrainian and English showed that in real communication the authors of letters often deviate from the universal principles of successful written interaction due to various factors: status-role and social asymmetry (choosing conflicting strategies and tactics), features of intercultural communication, etc.

Thus, in the process of analysis of Ukrainian and English business letters, frequent manifestations of communicative incompetence of the authors of the two languages were, first, cases of violation of the maximum amount of information, including its redundancy, due to inability to distinguish the main idea of the text. Moreover, in Ukrainian and English letters it manifested itself in different ways. The English letters contained several key ideas or topics that made them difficult to understand, the main idea was often formulated at the beginning of the text and not explained at the end so that the reader would pay attention to it and know exactly what to answer; in Ukrainian business letters superfluous information was given in the smallest details, there was an inappropriate, unreasonable division into paragraphs (a good communication strategy is this: to get the recipient to grasp what we need, you should make paragraphs different in size, and one of them - on one tape. Recipient in this case reads this line undoubtedly).

Secondly, non-compliance with the maxim of the method of information transfer, which was expressed in excessive emotionality and evaluation (which is a violation of the dominant officialbusiness style). Evaluation and subjectivity were more common in the Ukrainian style of business writing. This was expressed, for example, in the use of tactics to defend one's own opinion, sometimes self-presentation or the transition to informal communication. There has been a strategy of justification, which is often intertwined with a strategy of reducing the distance, which makes the transition to a family-friendly and humorous tone. Infrequent cases of non-compliance with the official tone of communication, use of words / phrases that degrade the dignity of employees, occurred mainly in Ukrainian business letters. Instead, the ethical component of English correspondence, which is realized in the principle of tolerance, in avoiding categoricalness, in the 
priority of politeness, in the ability to anticipate conflicts, is much higher than in business correspondence in Ukrainian.

Even the neutral tone of a business letter allows to see the author's commitment with the help of details: indicative file name, respect for human time (manifested in timely delivery of the letter with tasks, in the indication of the date of execution, not abuse of props "urgently", showing a certain level disrespect, etc.).

At the end of the research we would like to mention the role of extralinguistic means of business writing (font choice, paragraph division of text, use of postscripts), although their number is not as significant and the meaning is not as important as in oral communication. Therefore, the main influence on the recipient in correspondence is carried out by linguistic means, namely through the correct choice and use of language and speech material.

Summarizing the above, it should be noted that modern research on business communication, in particular business correspondence, confirms the connection between language and culture, these examples also illustrate the need to consider the national-cultural component in writing a business letter and especially in doing international business.

A comprehensive study of the relationship between language and culture helps to improve the forms, effectiveness of communication and international business communication. It remains to see one in another, and most importantly - through another.

\section{REFERENCES}

Ashley, A. A. A Handbook of Commercial Correspondence. Oxford Univ. press, 2000.

Bielawski, L., Parks, F.A. Organizational writing. Belmont, CA Wadsworth, 1987.

Brittney, L. E-mail and business correspondence. Moscow 2005.

Buber, M. Daniel. Dialogues on Realization. N.Y.: Holt, Reinhart and Winston, 1964.

Dảmovȧ, P. The Language of Law. A Stylistic Analysis with a Focus on Lexical (Binominal) Expressions [thesis], Masaryk University, Brno. 2007.

Danet, B. Legal Discourse. In: Van Dijk, T. A. Hand-book of Discourse Analysis. London: Academia Press, 1985. Vol. 1. 273-291.

Doubenko, E. Stylistic features of English and Ukrainian official-business texts in a comparative perspective. "Science and Education a New Dimension. Philology". 2017. V (28), Issue: 115.

Hiltunen, R. Chapters on Legal English: Aspects Past and Present of the Language of Law. Helsinki: Suomalainen Tiedeacademia, 1990.

Kappeler, D. Texts in Diplomacy. Language and Diplomacy. Malta 2001.

Krivchikova, N. L. Stylistic characteristics of a legislative text. "Journal of Language and Literature". 2015, Vol.6. No 2. 188-190.

Leech, G. N. Principles of pragmatics. L.; N. Y.: Longman, 1983.

Lisina, N. Stylistic Features of Legal Discourse: A Comparative Study of English and Norwegian Legal Vocabulary [thesis]. University of Oslo. 2013.

Matsko, O. M. Foreign word sintexts in diplomacy. "Word culture". 2000, Vol. 53/54. 143-149.

Shabunina, V. V. Legal English as a product of its history. "Language and conceptual pictures of the world", 2012. Vol. 42. Part 2. 426-432.

Thill, J. V., Courtland, L. B. Excellence in Business Communication. New York: Mc Graw Hill, Inc.1993.

Urbanova, L. A Reader in English Stylistics. Prešov 1986. 